\title{
Learning Model Based on Democratic Life
}

\author{
Şeyma Şahin, $\mathrm{PhD}$ \\ Ministry of National Education, Turkey \\ (iD) https://orcid.org/0000-0003-1727-4772
}

\author{
Abdurrahman Kılıç, $\mathrm{PhD}$ \\ Duzce University, Turkey
}

Contact: seyymasahin@gmail.com

\section{Abstract}

Our research aimed to evaluate the effectiveness of the democracy and human rights course taught with a "Learning Model Based on Democratic Life." The study was conducted with an action research design. The research study group, determined using purposeful sampling, consisted of 10 students taking a Democracy and Human Rights course at a state university in Turkey. Data were collected using "Process Evaluation Forms" and "Student Letters." Content analysis was used in the analysis of the data. We concluded that the students thought the Learning Model Based on Democratic Life supported their participation, was efficient and interesting, contributed to the formation of a democratic classroom environment, and enabled them to learn democracy in democratic ways.

Keywords: democracy, learning model based on democratic life, democracy and human rights course, student opinions, action research

Date Submitted: November 26, 2020 | Date Published: September 3, 2021

\section{Recommended Citation}

Şahin, Ş., \& Kılıç, A. (2021). Learning model based on democratic life. Journal of Educational Research and Practice, 11, 181-201. https://doi.org/10.5590/JERAP.2021.11.1.13

\section{Introduction}

Every governmental system aims to raise individuals who will keep themselves alive. Societies governed by democracy should also raise individuals who will maintain democracy through democratic education because democratic citizens are the guarantee of democratic order (Rainer \& Guyton, 1999). Democratic attitudes and values can be taught and are directly related to education. For the individual, the importance of education in making democratic behaviors and attitudes a part of life is indisputable (Harber, 2002). The goal of democratic education is to raise citizens who are independent, questioning, and analytical in their view of the world and who are profoundly aware of the rules and practices of democracy (Hotaman, 2010). Democracy education aims to raise people who can develop as democratic individuals, think freely, research, establish good relations with people, and make their own decisions (Gömleksiz \& Kan, 2008).

Democracy is a way of life; it is developed in the family, school, workplace, and other social organizations. Schools, where education is carried out on a programmed basis, have a significant impact on individuals' 
democratic attitudes and skills (Şahin, 2020). This is because no other institution can sustainably hold together such large numbers of young people (Cook \& Westheimer, 2006). Considering that citizens of democratic societies learn about democracy mostly through socialization in their youth, the importance of schools for the realization and development of democratic life will come to the fore (Claassen, 2019). For this reason, the task of developing democratic culture and values is considered among the basic tasks of curricula (Blair, 2003; Davis, 2003).

Although schools play an important role in democratic life, it is not possible to make individuals gain democratic values and behaviors as course subjects (Okutan, 2010). Democracy is best learned in a democratic environment. To develop the democratic habits of students who will continue the democratic management system in the future and to ensure the social and moral development required for this, environments must be created that are suitable for developing and strengthening democratic understanding in schools (Collins, 2013; Edelstein, 2011). The school should be considered as a "micro-society," and the basic criteria of democracy should be kept alive in this micro-society. For this purpose, democratic structures and processes should be formed in schools, and the principles and rules of democracy should be applied in decision-making processes. Schools should be turned into environments for "living democracy," and they should be organized in a way that allows students to be individuals who can adopt democratic thinking, values, and behaviors. Doing so will let democracy live in society (Edelstein, 2011; Gollob et al., 2010; Hotaman, 2010). In environments where education is conducted in an atmosphere of tolerance and respect, it may be possible to learn through democracy and encourage students' democratic attitudes. In such settings, justice is also provided; students are allowed to express their wishes and opinions, and students' participation is encouraged (Starkey, 2005; Vinterek, 2010). For this purpose, students should be provided with opportunities to use their freedom of thought and expression in an environment of tolerance, to participate actively and widely in management and decision-making mechanisms, and to live democracy by creating appropriate learning experiences in lessons (Levin, 1994; Lind, 2018; Okumuş \& Güven, 2018; Varnham et al., 2014).

There is a one-to-one relationship between democracy and student-centered education. In democracies, the individual is fundamental, and educational activities are based on students' interests, wishes, and abilities. People who have a voice in the state administration correspond to students who have a voice in the classroom, being alone with their responsibilities and managing their learning. In democracies, individuals can express their opinions freely and use their rights and freedoms within the framework of the laws. Student-centered education allows students to make their own choices according to their interests and abilities and to achieve as much as they are able (Şahin, 2020). In this context, for democracy to survive in the school environment, learning processes should not be "teacher-oriented" but "student-oriented," based on real-life problems and supporting the active participation of learners (Gollob et al., 2010). Students who are told to sit obediently in class and are not allowed to question and criticize will not be able to have a democratic, open-minded, and criticizing awareness (Kovacs, 2009). In democratic learning environments, learning is not controlled by the monopoly of the teacher. Students are given choices in how learning will take place (Jacobs \& Power, 2016). The teacher's role has changed from a traditional didactic, authoritarian role to a facilitating, personal role (Subba, 2014).

Although democratic school environments are important for raising good citizens with democratic awareness, unfortunately, the typical teaching style is still authoritarian in many countries, especially in low-income countries. Student-centered education is not preferred and cannot be implemented effectively (Schweisfurth, 2014). Arseven et al. (2016) found that teachers are far from student-centered education in the planning, implementation, and evaluation teaching. Teachers use traditional teaching methods and techniques widely, and they don't believe in the applicability of the student-centered education approach. Şahin (2020) determined that some of the teachers prefer being an authority rather than a guide in the classroom. On the other hand, teachers who profess to a belief in student-centered education have inconsistencies in their views. 
They may not understand student-centered education and or believe in its philosophy. Teachers have perceptions that both democracy and student-centered education are beautiful in theory but dysfunctional in practice. According to the metaphor study conducted by Duru (2015) on preservice teachers, it was revealed that $85.7 \%$ have teacher-centered beliefs, $4.1 \%$ have student-centered beliefs, and $10.1 \%$ have both teacherand student-centered beliefs.

Some teachers who believe in the importance of student-centered and democratic classroom environments fail in practice. Zabeli et al. (2018) revealed that teachers seem to understand the student-centered teaching philosophy, but they have a superficial view of how these approaches can be applied in the classroom environment. Bostan (2007) found that, although teachers state that they use student-centered education, they do not fully know the features of it. Demir \& Özden (2013) concluded that teachers believe in the importance of using student-centered strategies, methods, and techniques, but they cannot apply these strategies, methods, and techniques in their classrooms because of various problems. In their study, Maden et al. (2011) found that teachers' perception levels toward the usefulness of student-centered teaching are high, whereas their perception of readiness is low. Saracaloğlu and Karasakaloğlu (2011) reported that teachers avoided using some student-centered methods and techniques because of crowded classes and other physical limitations. Bayram-Jacobs and Hayırsever (2016) determined that preservice teachers have knowledge about student-centered education but cannot organize their teaching-learning practices in line with this approach.

Deficiencies in both the adoption of a student-centered and democratic education approach and the adaptation of this understanding to education are evident in the literature reviews. Our study aimed to evaluate the effectiveness of the Learning Model Based on Democratic Life, which was created based on student-centered and democratic life. Thus, it is aimed to provide a model that can be used by teachers and academicians in every major. Another aim of our research was to provide students with various knowledge, skills, and values at the end of their Democracy and Human Rights course, which was taught with this model.

\section{Method}

Our study was conducted with action research, one of the qualitative research designs. With action research, we looked at the learning process critically with a systematic approach. Thus, we thought that it could be possible to identify the problems and solutions encountered in practice and to develop various strategies for effective and qualified education.

The action research process consisted of several stages: collecting data on the research subject, analyzing and interpreting these data, and making various action decisions to make positive changes. We created a semester plan, and the first action plan process was carried out accordingly. The first action plan process lasted for 5 weeks; at the end of the process, students were given process evaluation forms and asked to evaluate the process, and the collected data were analyzed. According to the decisions taken at the end of the first action plan process, the second action plan process was put into practice. The second action plan also lasted for 5 weeks, and at the end of the process, the students were again given process evaluation forms, and the data were collected and analyzed. According to the decisions taken at the end of the second action plan process, the third action plan was put into practice. The third action plan lasted for 2 weeks. At the end of the 15th week, the application was ended.

\section{Study Group}

The purposeful sampling method was used to determine the study group. Thought to be suitable for the determined Learning Model Based on Democratic Life, an elective course, Democracy and Human Rights, was selected, and the students who chose the course formed the study group. 
In this context, the study group consisted of 10 students who were enrolled in this course. Seven of the participants were in the field of Education Management and Supervision Department, and three of them were continuing their master's degree programs in Curriculum and Instruction. Five of the participants were women, and five were men. Their majors were Mathematics, Turkish, History, Social Studies, Classroom, and Preschool Teaching. Thus, diversity was created among the study group participants who were from different genders and majors.

\section{Application Process}

The course lasted 15 weeks. During the implementation process, the Learning Model Based on Democratic Life was applied. Face-to-face training was held for the first 4 weeks; after the 4 th week, the training was switched to distance learning because of the global epidemic (COVID-19). Although the design of the course was prepared for face-to-face education, after the transition to distance learning, the model was easily adapted without the need to change much. No changes were made in the methods and techniques used throughout the process; the only adaptations were made for distance learning.

The process was carried out as group works. The class was divided into two groups of five students, and the groups were named the Human Rights group and Democracy group. Each group included a chairman, a secretary, and three members. Each group member served as chairman and secretary, in turn, and the secretary of that week became the chairman for the next week. The Human Rights group ruled for 5 weeks and then the Democracy group ruled for the next 5 weeks, when the other group served as opposition, and the last 2 weeks were governed as a coalition (two groups together). For this purpose, elections were held and the president and secretary of each 2 weeks were determined according to the votes cast. The president and secretary of the ruling group of that week also served as the president and secretary of the shura.

The model shown in Figure 1 consists of two main groups: processes and products. Processes consisted of two elements: learning activities and assessment. Products consisted of knowledge, skill, value, and attitude expected to emerge at the end of the process.

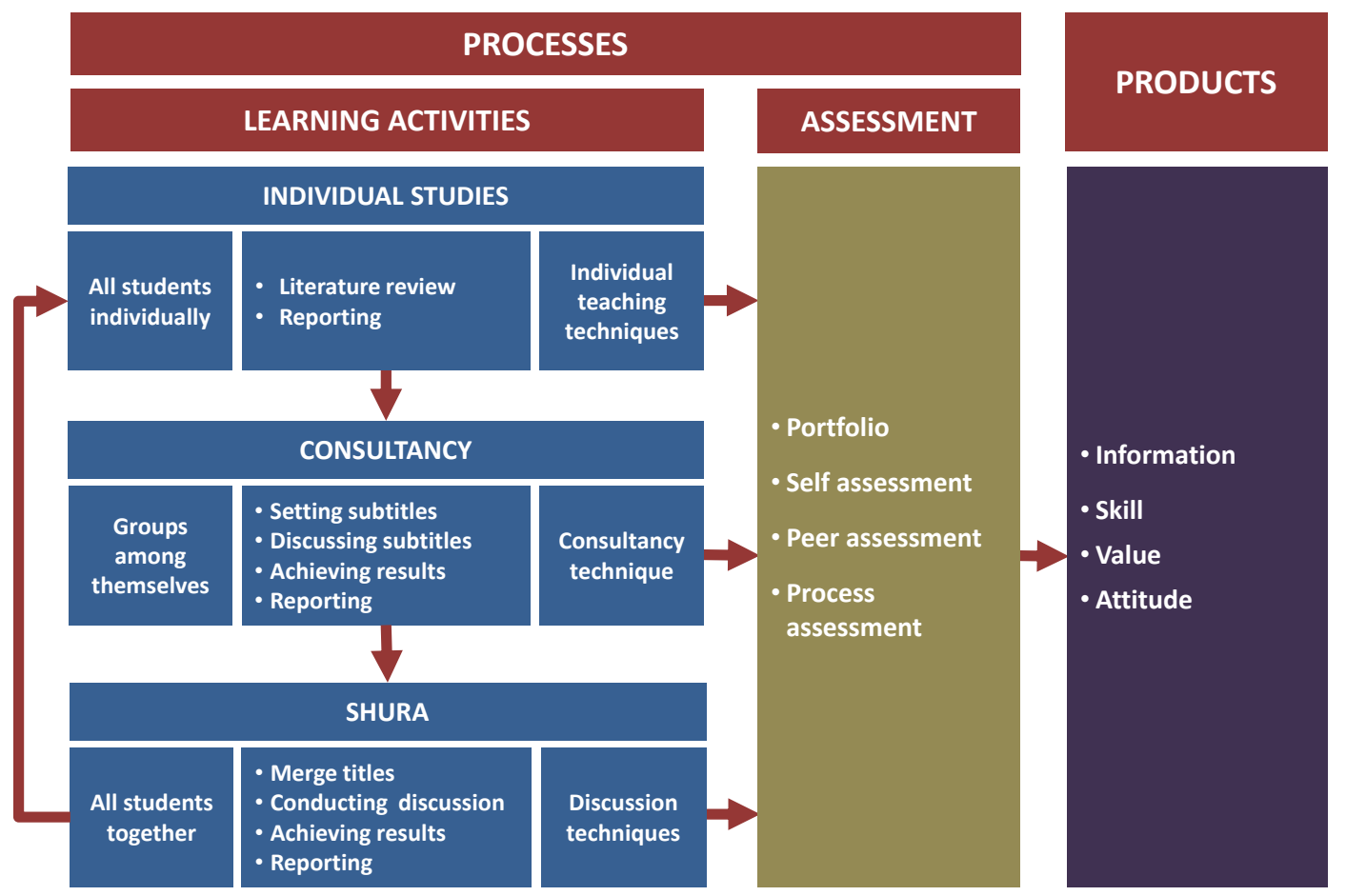

Figure 1. "Learning Model Based on Democratic Life" Designed to be Used in the Process 


\section{Processes}

\section{Learning Activities}

Activities were organized as a cyclical process consisting of individual studies, consultancy, and shura, referring to the formation and development of democracy at the individual, society, and state levels. In a democratic society, the individual is the most important component. Free and responsible individuals constitute the philosophical foundation of democracy. In democratic societies, the individual, individual rights and freedoms, and the individual's right to self-development are prioritized (Heinö, 2009). However, the individual is not a self-sufficient being who is completely independent of the rest of the universe. The individual is born, grows, and lives in relationships with other individuals (Wolfe, 1923). People have always survived in societies throughout history. Being a society requires mutual relationships and activities for common purposes. The basic measure of a democratic society is that citizens can unleash their potential by intentionally participating in social life and working for the good of society (Dewey, 2001). Democracy regulates not only the relationship between individuals but also the individual's relationship with the state. In democracies, providing a humane life for individuals to reveal their potential is the reason for the existence of the state. Democratic states have characteristics shaped by the preferences of their societies (Çelik, 2018).

Individual studies were carried out individually by all students before the course and constituted the basis of the learning process. Democratic education supported individual learning activities arising from their own needs, curiosity, and interests to strengthen an area in which the individual was weak and to develop more knowledge and skills in subjects they love (Güleç et al., 2012). In democratic learning environments, students' individual studies are necessary for them to gain personal experience and bring their personal experiences to a course (Gollob et al., 2010). Considering that a successful collaboration starts with individual talents, individual responsibility, and motivation, individual learning is both a prerequisite and a complementary role for cooperation. Moreover, individual learning is also a necessity for individual accountability (Yadin \& Or-Bach, 2010).

Before consultancy and shura, each student had the task of searching the literature individually; finding at least two articles suitable for the subject; reading, summarizing, and reporting them to gain personal experience; and becoming prepared for the consultancy. Students used individual techniques suitable for their learning style while performing their tasks. To support students, article sharing was provided from the beginning of the process. To give each individual an opportunity to create their subtitles, the subject headings were kept wide and not limited. The students sent their reports to the email address determined for evaluation by the instructor before the consultancy and shura.

\section{Consultancy}

Consultancy meant debate on a certain subject, discussion of various ideas to reach the best decision, and people chatting together to come up with common opinions (Yargıc1, 2008). Consultancy requires working as a group. In democratic educational environments, group works are as important as individual works. Interactions in peer groups during the learning process had a positive effect on students being active learners who are open to diversity and critical thinking (Nagda et al., 2003). Interactions and experiences in the classroom environment strengthen students' social development. They provide opportunities for students to understand the advantages of getting in touch with people who are different from them and to learn about different cultures, lifestyles, and people. In such an environment, students also gain some values such as cooperation, trust, responsibility, and democratic behaviors (Ahmad et al., 2015; Jacobs \& Power, 2016).

Each group did the consultation on Tuesdays between 12:00 and 13:00. The presidents were responsible for managing the consultancy; secretaries were responsible for reporting and sending the report to the specified email address. In the consultancy, the literature was evaluated based on individual reports, subject subtitles were determined, results were obtained by discussing each subtitle by the group, and the results were 
reported. In consultancy, students were to be in mutual relationships with each other and participated in activities for a common purpose. The students complied with the democratic rules of discussion and developed this skill while following consultancy rules:

- Everyone should come to consultancy with preparation.

- The right to speak should be given in turn.

- $\quad$ During the interviews, everyone expresses their opinions with reasons.

- The opinions of others are also considered to be valuable.

- Even though there may be some unpleasant views, they are to be approached with respect and tolerance.

- Attention should be paid to courtesy rules in speaking and listening.

- Everyone has one vote. If possible, a decision is taken unanimously, not by majority votes.

- The decisions taken are collective and should be recognized by all.

\section{Shura}

Shura means a meeting held for talking and discussing topics; it is also the place where this meeting is held, the assembly (Altuntaş, 2013). Shura is an essential method for obtaining an idea or choosing one of the ideas. Moreover, it is also the method for deciding all public issues, such as political, economic, and social issues (El-Gindi, 2008). Its goals are to liberate people, protect the interests of society, and organize things so that people can live in safety and happiness. It requires accepting that everyone can have different ideas and that everyone's ideas are important and valuable (Yargic1, 2008). Shura enables the formation of free and pluralistic environments. By creating such environments, people can use their potentials actively and can realize themselves both individually and socially (Şahinalp, 2017).

Shura was held on Tuesdays between 13:00 and 14:30 and all groups/students participated. Faculty members participated in shura as observers during the process and as commentators at the end of the process. Immediately after the consultation, the head of the opposition was assigned to share the subtitles in Google Classroom, and the president of the ruling was assigned to combine the subtitles of both groups for discussion at the shura.

Shura included the processes of combining titles, conducting discussions, reaching conclusions, and reporting. In the teaching of the courses, it was important to use methods and techniques that have democratic features and put the students at the center. It was also important to design the courses in a way that would suit the learning speed of the students, allow them to choose, and provide them with convenience for research and analysis. It was necessary to create a space where students could express their discourse by comparing various views and perspectives and to encourage them to question and think critically (Simó et al., 2016). Therefore, techniques such as brainstorming, opinion development, opposite panels, argumentation, Socratic questioning, debate, case study, problem solving, and drama were used. These techniques contributed to the students gaining skills, such as cooperation, communication, critical thinking, problem solving, and values, such as tolerance, responsibility, respect, cooperation, and respect for differences. In this context, each shura was carried out using a different discussion technique. The subjects discussed in the shura and the techniques used are listed in Table 1. 
Table 1. Subjects and Techniques Used

\begin{tabular}{|c|c|c|c|}
\hline Management & Date & Subjects & Techniques \\
\hline & Feb. 17-21 & Meeting, providing information about the & \\
\hline & Feb. 24-28 & course & \\
\hline \multirow{7}{*}{$\begin{array}{l}\text { Ruling human } \\
\text { rights group }\end{array}$} & & Definition of human rights and basic concepts & \\
\hline & Mar. 2-6 & $\begin{array}{l}\text { Classification of fundamental rights and } \\
\text { freedoms }\end{array}$ & Idea development \\
\hline & Mar. 9-13 & $\begin{array}{l}\text { Historical development of human rights in the } \\
\text { world }\end{array}$ & Opposite panel \\
\hline & Mar. 16-20 & Pandemic break & \\
\hline & Mar. 23-27 & $\begin{array}{l}\text { Historical development of human rights in our } \\
\text { country }\end{array}$ & Argumentation \\
\hline & $\begin{array}{l}\text { Mar. 30- } \\
\text { Apr. } 3\end{array}$ & Human rights in the world and our constitution & Circle technique \\
\hline & Apr. 6-10 & $\begin{array}{l}\text { Human rights and management systems } \\
\text { relationship }\end{array}$ & Speaking ring \\
\hline \multirow{5}{*}{$\begin{array}{l}\text { Ruling } \\
\text { democracy } \\
\text { group }\end{array}$} & Apr. 13-17 & Definition of democracy and types of democracy & Circle technique \\
\hline & Apr. 20-24 & Historical development of democracy & Seminar \\
\hline & $\begin{array}{l}\text { Apr. 27- } \\
\text { May } 1\end{array}$ & Basic features and elements of democracy & Socratic questioning \\
\hline & May 4-8 & Islam, democracy, and secularism & Discussion \\
\hline & May $11-15$ & Democracy and civil society & Case study \\
\hline \multirow[b]{2}{*}{ Coalition } & May $18-22$ & Human rights and democracy in education & Story creation \\
\hline & May 25-29 & $\begin{array}{l}\text { Human rights problems and democratization } \\
\text { efforts }\end{array}$ & The Six Hat Thinking \\
\hline
\end{tabular}

The chairman of the ruling group was responsible for managing the shura according to the technique listed in Table 1, and the secretary of the ruling group was responsible for reporting. Techniques were determined at the beginning of the semester, but at the end of the first action process, some arrangements were made according to student views. We arranged the technique to be used following the format of the course and sent it to the students via Google Classroom 4-5 days before the course. Particularly, we ensured that the chairman who would lead the discussion was prepared to use that technique. At the beginning of the shura, a short explanation was made about the technique to be used that week. In the shura, the titles of ruling and opposition were handled one by one according to the determined teaching technique, and then some results were reached. The lecturer of the course made a 15- to 20-minute evaluation at the end of the shura.

\section{Assessment}

Assessment, which is a part of the democratic learning process, focuses on the process; the student is also involved in this process. Assessment encourages learning and growth by providing useful feedback on what the students and teachers needed as they moved toward the learning goals (Andrade et al., 2012). Assessment 
is a democratic process that allows students to evaluate themselves, each other, and their teachers, and at the same time, allows the teachers to evaluate themselves as learners (Şahin, 2015).

The assessment was done with portfolio, self, peer, and process assessments. The portfolio was received electronically, and each group prepared a common portfolio. It included individual study reports, consultancy reports, and a shura report. The reports submitted by the students were filed by the researchers in the computer environment and scored every week. Two forms, named Individual Scoring Form and Group Scoring Form, were created for the assessment of individual reports and group reports. Self and peer assessments were made three times in total, at the end of each action phase. For this purpose, three different self-assessment forms and three different peer-assessment forms were prepared to be applied at the end of each stage. The assessment of the course was made as follows: portfolio group score, 40\%; portfolio individual score, 40\%; self-assessment, 10\%; peer assessment, $10 \%$.

\section{Products}

Democratic education encourages knowledge-based intellectualism but does not see it as sufficient. It aims to equip students with skills such as self-efficacy, self-confidence, self-control, self-discipline, autonomy, analytical and critical thinking, and problem solving, as well as social skills, such as communication, taking initiative, entrepreneurship, participation, conciliation, and decision making (Özpolat, 2010). Democratic education is based on the belief that each person is important and dignified and is established on the importance of valuing oneself and others. It guides individuals to have values such as tolerance, empathy, trust, honesty, justice, solidarity, patriotism, respect for human rights, rule of law, responsibility, equality, pluralism, and respect for differences (Botha et al., 2016; Özpolat, 2010; Petrova-Gjorgjeva, 2009). In this context, values should be included in the curriculum and reflected by students through school and classroom interactions. Thus, it may be possible for children to appreciate and adopt basic values and develop a sense of commitment (Subba, 2014).

In this context, the products we expected to emerge in our research at the end of the process were knowledge, skill, value, and attitude. At each step of the process, the aim is for students to gain knowledge at different levels regarding the subject area of the course. This dimension includes the skills and values that students are expected to acquire at the end of the process. These skills are inquiry, collaboration, communication, critical thinking, problem solving, and decision making, etc. Values include love, tolerance, empathy, justice, responsibility, solidarity, and respect for differences. At the end of the course, one of the expected products is that students develop a positive attitude toward the course.

\section{Data Collection}

Data were collected at the end of the first, second, and third action phases. Data were collected by email. Process Assessment Forms and Student Letters were used in data collection.

\section{Process assessment form}

We developed the form and finalized it in line with the expert opinions taken from two academicians who are experts in educational sciences. The form included the following questions:

- What were the contributions of the course process to you in terms of knowledge, skills, and values?

- What were your favorite things to do during the lesson?

- What were the problems you encountered with lesson design?

- What were the problems you encountered during the distance education process of the course? 
- What were the problems you encountered in the consultancy process? What are your suggestions for solving the problems and for the process to be effective?

- What are the problems you encounter in the shura? What are your suggestions for solving the problems and for the process to be effective?

- What would you suggest to improve the course process?

- What do you want to add?

\section{Student letters}

Letters were requested at the end of the semester from each student to express their feelings and thoughts about the process.

\section{Analysis of the Data}

Process assessment forms were analyzed at the end of the first and the second action plan, and student letters were analyzed at the end of the third action plan. The data analysis process was carried out in three stages: (1) organizing the data, (2) summarizing the data, and (3) associating/interpreting data (Kılıç et al., 2019). During the data editing phase, the forms were coded as $\mathrm{S} 1, \mathrm{~S} 2, \ldots, \mathrm{S} 1 \mathrm{O}$ for each student. These codes are also used in direct quotations in the presentation of the findings. Summarizing the data was carried out by content analysis. Content analysis involved a detailed and careful examination of a particular material to define patterns, categories, or meanings (Kılıç et al., 2019). At this stage, processes were carried out: encoding the data, distributing coded data into categories, combining the data in upper categories, and creating subcategories. In the association/interpretation stage, common points and differences between the data collected with different data collection techniques were examined, and a new structure was formed by relating the emerging categories to each other.

\section{Results and Discussions}

Results are presented under two headings: (1) negative opinions about the process and (2) positive opinions about the process.

\section{Negative opinions regarding the process}

Negative opinions of the students about the process are presented under separate headings as negative opinions at the end of the first, the second, and the third action plans.

Negative opinions at the end of the first action plan. The negative opinions of the students about the first action plan process as a result of analyzing the process assessment forms are given in Table 2: 
Table 2. Student Negative Opinions at the End of the First Action Plan

\begin{tabular}{|c|c|c|}
\hline \multicolumn{2}{|l|}{ Categories } & Codes \\
\hline \multirow{3}{*}{\multicolumn{2}{|c|}{ Individual studies }} & Too long individual preparation time \\
\hline & & Having trouble searching and finding articles \\
\hline & & Not clear/too broad subject boundaries \\
\hline \multirow{2}{*}{\multicolumn{2}{|c|}{ Consultancy }} & Group members not fulfilling their responsibilities \\
\hline & & Failing to discuss differences with tolerance \\
\hline \multirow{13}{*}{ Shura } & \multirow{5}{*}{ Techniques } & Using techniques that are not suitable for distance education \\
\hline & & Not using techniques following their essence \\
\hline & & Using techniques distracting from the subject \\
\hline & & Using techniques as a goal rather than tools \\
\hline & & Using different techniques every week \\
\hline & \multirow{3}{*}{$\begin{array}{l}\text { Student } \\
\text { participation }\end{array}$} & Low interaction \\
\hline & & Not actively participating in course \\
\hline & & Having trouble concentrating during the course \\
\hline & \multirow{3}{*}{ Time } & Continuous change of the course time \\
\hline & & Long course duration \\
\hline & & Not using time effectively \\
\hline & \multirow{2}{*}{ Instructor } & Being less active \\
\hline & & Not managing the process \\
\hline \multirow{7}{*}{\multicolumn{2}{|c|}{ Reporting }} & Too much and tiring \\
\hline & & Constituting an important part of the course \\
\hline & & Writing both consultancy reports and shura reports \\
\hline & & Time too short for submission \\
\hline & & Waiting for the individual reports before submitting the report \\
\hline & & Secretary's negligence to submit the report \\
\hline & & $\begin{array}{l}\text { Secretary's effort to take notes and follow the course at the same } \\
\text { time }\end{array}$ \\
\hline \multirow{4}{*}{\multicolumn{2}{|c|}{ Assessment }} & Being grade oriented \\
\hline & & Not grading correctly/fairly \\
\hline & & Not disclosing the reasons for the given grades \\
\hline & & Posting grades publicly \\
\hline \multirow{5}{*}{\multicolumn{2}{|c|}{ Distance Learning }} & No Internet at home \\
\hline & & Connection problems \\
\hline & & Ear, eye, neck pain \\
\hline & & Inability to perceive voice tone, gestures \\
\hline & & Not being suitable for distance education \\
\hline
\end{tabular}

As seen in Table 2, at the end of the first action plan, students had various criticisms under a total of six categories: (1) individual studies, (2) consultancy, (3) shura, (4) reporting, (5) assessment, and (6) distance learning. 
We found that students generally have difficulties in finding resources in individual studies and think that the subject has broader limits. The problem with consultancy was that each member did not come with the necessary preparations.

We also found that students have a criticism, especially toward teaching techniques. The students did not think the techniques used in the shura were effective. This may be the result of students' traditional perceptions that they can learn better with lectures. In her study, Şahin (2020) determined that students' perceptions of education are mostly focused on lecture. In this respect, Frambach et al., (2014) discussed how students' cultural origins shape their discussion behaviors and skills within group activities in studentcentered education. A comparative study was conducted in three schools in East Asia, Western Europe, and the Middle East using a student-centered approach. Especially in nonwestern schools, we have found that students avoid expressing their opinions, asking questions, and discussing their opinions with others. Another reason for the complaints about the use of methods and techniques is that student-centered techniques seem more challenging and different to students in distance education. On the one hand, the students thought that they could not actively participate in the lesson, and on the other hand, they wanted the instructor to be more effective in the process. This seems to be a contradictory situation.

Another issue that was criticized extensively is reporting. Some criticisms in this category were having too much reporting work, less time for reporting, and having trouble sending the group and class report due to waiting for individual reports. Students also complained about the grades given and announced each week.

Finally, in the distance education category, problems such as no Internet at home and disconnection were mentioned.

Negative opinions at the end of the second action plan. The negative opinions of the students about the second action plan process as a result of analyzing the process assessment forms are given in Table 3:

Table 3. Student Negative Opinions at the End of the Second Action Plan

\begin{tabular}{lll}
\hline Categories & Codes \\
\hline \multirow{2}{*}{ Individual studies } & $\begin{array}{l}\text { Difficulty in finding resources } \\
\text { Conducting a large literature review }\end{array}$ \\
\hline \multirow{2}{*}{ Techniques } & $\begin{array}{l}\text { Some techniques are not suitable for distance education } \\
\text { Some techniques are not suitable for the subject } \\
\text { Shura }\end{array}$ & Students not getting ready for the technique \\
\cline { 2 - 3 } & Student & Speaking in order \\
& Interrupting the speaker \\
& Time & Laughing when someone is talking \\
\cline { 2 - 3 } & Content & Encreasing class hours \\
& Not describing the ideal \\
\hline \multirow{3}{*}{ Distance learning } & Connection problems \\
& Headache \\
& Inability to perceive voice tone, gestures \\
\hline
\end{tabular}

The categories in Table 3 were reduced to three: (1) individual studies, (2) shura, and (3) distance education. 
When Table 3 is examined, a significant decrease in the codes of students' negative opinions is evident. At the end of this action phase, no negative opinion emerged in the consultancy, reporting, and assessment categories. Students still had negative thoughts about individual studies, techniques, and student participation, but there was a decrease in the number of negative codes in these categories.

The views of the students that "the lesson ends before reaching a definite conclusion" and "the ideal is not defined and the reality is not explained" were interesting. In a student-centered approach, students are allowed to explore various ways of learning, be creative and have fun, leaving their comfort zones (DiazLefebvre, 2004). In student-centered teaching, the teacher provides the necessary foundation for learning but does not directly give the content to be learned. Instead, the teacher designs classroom activities that will help students discover important information (Brackenbury, 2012). Student-centered learning activities are controlled by students and can even take place without a teacher (Saulnier et al., 2008). In this context, we thought that these views of the students were also due to their traditional, teacher-centered understanding.

Negative opinions at the end of the third action plan. The negative student opinions about the third action plan are given in Table 4:

Table 4. Student Negative Opinions at the End of the Third Action Plan

\begin{tabular}{ll}
\hline Categories & Codes \\
\hline Design of the course & $\begin{array}{l}\text { The government-opposition practice was unnecessary } \\
\text { The instructor should have been more controlling and active }\end{array}$ \\
\hline Individual studies & Article sharing negatively affected the research spirit \\
\hline \multirow{2}{*}{ Shura } & $\begin{array}{l}\text { Time always exceeded } \\
\text { Some techniques had little effect }\end{array}$ \\
\hline \multirow{2}{*}{ Reporting } & It was unnecessary to write an individual report \\
& Reporting time should have been more flexible \\
\hline
\end{tabular}

When Table 4 is examined, at the end of the third action plan process, we found that students have some criticisms under a total of four categories: (1) design of the course, (2) individual studies, (3) shura, and (4) reporting. On the other hand, at the end of this process, we found that students indicated a considerably smaller number of criticisms compared with the other action plan processes. We found that the action research process was effective in solving the problems.

\section{Positive opinions regarding the process}

The positive opinions of the students about the process as a result of analyzing the process assessment forms and student letters are presented in Table 5: 
Table 5. Student Positive Opinions Regarding the Process

\begin{tabular}{|c|c|c|}
\hline Categories & & Codes \\
\hline \multirow{13}{*}{ Course design } & \multirow{2}{*}{$\begin{array}{l}\text { Student } \\
\text { participation }\end{array}$} & It was a student-centered design \\
\hline & & Students were included in the process \\
\hline & \multirow{2}{*}{ Efficiency } & It was successful, efficient, and stimulating \\
\hline & & It was planned, orderly, and systematic \\
\hline & \multirow{5}{*}{ Attractiveness } & It was the most different course \\
\hline & & It was confusing, intriguing \\
\hline & & It was nice to have everyone in every task \\
\hline & & The ruling-opposition practice was interesting \\
\hline & & The atmosphere of democracy was experienced \\
\hline & \multirow{4}{*}{$\begin{array}{l}\text { Application of } \\
\text { democracy }\end{array}$} & The purpose of the course was suitable for the model \\
\hline & & Democracy was taught in a democratic way \\
\hline & & The concepts of democracy were taught in practice \\
\hline & & The working system of the parliament was seen in practice \\
\hline \multirow{4}{*}{$\begin{array}{l}\text { Individual } \\
\text { studies }\end{array}$} & \multirow{2}{*}{ Efficiency } & The individual preparation was necessary and effective \\
\hline & & Doing research and reading articles were useful \\
\hline & \multirow{2}{*}{$\begin{array}{l}\text { Article } \\
\text { support }\end{array}$} & Article support saved time \\
\hline & & Article support made it easy to learn \\
\hline \multirow{5}{*}{ Consultancy } & \multirow{2}{*}{ Efficiency } & The boundaries of the subject were determined \\
\hline & & Missing points in individual studies have been completed \\
\hline & \multirow{3}{*}{ Group study } & It was productive to reach a common view with the group \\
\hline & & Group synergy was efficient \\
\hline & & The group work continued with tolerance and respect \\
\hline \multirow{13}{*}{ Shura } & \multirow{9}{*}{ Techniques } & Different teaching techniques were experienced \\
\hline & & The techniques served the purpose of the course \\
\hline & & Techniques created a democratic classroom environment \\
\hline & & The technique contributed to professional development \\
\hline & & The techniques enabled multiple thinking \\
\hline & & Techniques saved the course from being boring \\
\hline & & Techniques ensured the permanence of knowledge \\
\hline & & The techniques provided everyone the opportunity to talk \\
\hline & & Learning while discussing was effective \\
\hline & \multirow{3}{*}{$\begin{array}{l}\text { Student } \\
\text { participation }\end{array}$} & The learning environment was interactive \\
\hline & & All students participated actively in the course \\
\hline & & Everyone expressed their thoughts freely \\
\hline & Content & It was nice to talk about daily life issues \\
\hline
\end{tabular}




\begin{tabular}{ll}
\hline & It was efficient to hear different thoughts/ideas \\
\cline { 2 - 3 } & The instructors were constructive and positive \\
& $\begin{array}{l}\text { The instructor's comments were stimulating } \\
\text { The active participation of the instructors was nice }\end{array}$ \\
\hline Assessment & $\begin{array}{l}\text { No one experienced any anxiety about the grades } \\
\text { Assessing the individual tasks before the class was comforting }\end{array}$ \\
\hline Distance learning & Distance education contributed to the design of the course \\
\hline
\end{tabular}

As shown in Table 5, we found that the students had various opinions under a total of six categories: (1) course design, (2) individual studies, (3) consultancy, (4) shura, (5) assessment, and (6) distance learning.

The students thought that the design of the course supported student participation, was efficient and interesting, appropriate for the course, and enabled them to learn democracy democratically and practically. Supporting this result, Şanlı and Altun (2015) state that educational activities are important for the formation of democratic culture in schools, Ylldırım (2018) reports that democratic practices in the school environment are important for students to gain democratic attitudes, and, additionally, Tahiroğlu and Aktepe (2015) assert that democracy education activities positively affect the development of students' democratic values.

The students found the precourse studies efficient and they were satisfied with the article support provided to them. Supporting this result, the literature showed that preclass work at home increased students' active participation and success in the course (Frydenberg, 2012; Herold et al., 2012; Ökmen, 2020; Stone, 2012; Talbert, 2012). Garcia (2018) revealed that there was a strong and positive correlation between precourse preparation and final course score. Yamane (2006) stated that precourse preparation is particularly important for forming a discussion-based course. Similarly, Ronkainen (2015) reported that giving written tasks to students before the lesson is effective in terms of getting to read the content of the subject and thinking about it before the lesson.

The students thought that consultancy was productive, and working as a group and reaching a common view by sharing workload was positive. Our results confirmed the study by Subba (2014), who found that students learn best when they are cooperatively responsible for their learning. Similarly, Carpenter and Pease (2013) indicated that students who engage in effective collaboration with their peers achieve better academic results, establish stronger social relationships, and have more psychological well-being. Furthermore, Hurst et al. (2013) asserted that social interaction between students during the course improved their learning, critical thinking, and problem-solving skills.

Students reported that the techniques were compatible with the design of the course, increased participation, and made the lesson fun. Students enjoyed participating in the shura, listening to the content and the ideas of the lecturer. Supporting our results, Platt et al. (2014) showed that highly interactive classroom environments have a positive effect on student satisfaction.

The students did not have grade anxiety and thought it was positive to evaluate individual tasks before the lesson. The students also believed that distance education contributed to the design of the course. This is an important finding. Because, although the course was planned by face-to-face education and adapted to distance education, students confirmed that it was successful.

The opinions of the students about courses' contribution to them are given in Table 6. 
Table 6. Student Opinions Regarding Course Contribution

\begin{tabular}{|c|c|c|}
\hline \multicolumn{2}{|l|}{ Categories } & Codes \\
\hline \multirow{6}{*}{\multicolumn{2}{|c|}{ Democracy knowledge }} & Having information about subjects \\
\hline & & Learning new concepts and their philosophy \\
\hline & & Deepening their knowledge \\
\hline & & Testing their knowledge and reconstructing \\
\hline & & Understanding how little they know \\
\hline & & Learning the background of the topics \\
\hline \multirow{4}{*}{\multicolumn{2}{|c|}{ Democracy view }} & Changing their perspective of democracy \\
\hline & & Understanding the value of democracy \\
\hline & & Making democracy the focus of their life \\
\hline & & Changing the view of democracy in a religious dimension \\
\hline \multirow{10}{*}{$\begin{array}{l}\text { Elements of } \\
\text { democracy }\end{array}$} & $\begin{array}{l}\text { Fundamental } \\
\text { rights and } \\
\text { freedoms }\end{array}$ & $\begin{array}{l}\text { Being aware of rights and freedoms } \\
\text { Being a person who respects the rights }\end{array}$ \\
\hline & Cooperation & Gaining a tendency to cooperate \\
\hline & \multirow{2}{*}{ Consultation } & Giving importance to democratic decision making \\
\hline & & Understanding the importance of consultation \\
\hline & \multirow{2}{*}{ Leadership } & Gaining leadership features \\
\hline & & Gaining entrepreneurship features \\
\hline & Opposition & Learning to be in opposition \\
\hline & \multirow{3}{*}{ Citizenship } & Knowing their responsibilities better \\
\hline & & Fulfilling their responsibilities \\
\hline & & Strengthening of social relations \\
\hline \multirow{4}{*}{\multicolumn{2}{|c|}{ Thinking skills }} & Gaining the ability to comment \\
\hline & & Gaining critical-thinking skills \\
\hline & & Learning questioning \\
\hline & & Approaching events/news with a new perspective \\
\hline \multirow{3}{*}{\multicolumn{2}{|c|}{ Human values }} & Changing perceptions of values \\
\hline & & Gaining tolerance value \\
\hline & & Developing from the humanitarian perspective \\
\hline
\end{tabular}

Table 6 confirms that the students thought that the course had positive contributions to them in the areas of (1) knowledge, (2) democracy view, (3) social skills, (4) thinking skills, and (5) human values.

Students believe that they have learned new knowledge and concepts about democracy in depth, reconstructed their existing knowledge, and also experienced changes in their view of democracy. Supporting this result, Scott et al. (1997) stated that more effective and permanent learning occurs in classroom environments where students are active. 
The students also believed they had acquired the characteristics of effective citizenship, such as paying attention to and respecting fundamental rights and freedoms, consultation and democratic decision making, giving importance to cooperation, effective leadership, being the opposition, and fulfilling their responsibilities. Supporting this result, Subba (2014) stated that, in classroom environments with democratic practices and democratic experiences, students gain democratic understanding and skills. Hotaman (2010) and Yeșil (2004) asserted that techniques such as discussion, problem solving, brainstorming, case study analysis, and creative drama contribute to developing democratic behaviors in students. Additionally, Şanlı and Altun (2015) stated that when students are allowed to think, discuss, criticize, and compromise within the framework of democratic rules, they can gain democratic attitudes and behaviors more easily and permanently.

Students believed that they acquired critical thinking, questioning, and interpretation skills and that they experienced changes and developments in human values. Supporting this result, Yeşilyurt (2019) stated that the discussion technique gives students democratic features, such as interpretation and critical-thinking skills, as well as respect for the opinions of others. Benesch (1993) reported that, for the development of thinking skills, there is a need for a democratic learning process in which daily life issues are brought up and discussed, and students participate actively. Similarly, Winton (2008) stated that democratic education prepares students for critical thinking and provides them a social perspective with which to examine the facts. Moreover, Patrick (1986) noted that democratic environments are needed for the development of critical thinking.

\section{Conclusions}

We concluded that the students thought the Learning Model Based on Democratic Life supported their participation, was efficient and interesting, contributed to the formation of a democratic classroom environment, and enabled them to learn democracy in democratic ways. The students considered the discussion techniques used in the shura to be efficient, increased their participation in to course, ensured the permanence of knowledge, and kept the course interesting. Students believed that they learned new knowledge and concepts about democracy in depth, experienced changes in their perception of democracy, and gained knowledge about the elements of democracy. The students asserted that they gained effective citizenship characteristics, such as giving importance and respect to fundamental rights and freedoms, making consultations and democratic decisions, giving importance to cooperation, being effective leaders, being the opposition, and fulfilling their responsibilities. Thus, with this model, we concluded that students both learned democracy and learned through democracy. The students thought that they gained thinking skills such as critical thinking, questioning, and interpretation and also experienced changes and developments in human values with the model.

In the light of these results, we suggest using the Learning Model Based on Democratic Life that enables students to learn democracy by experiencing it in different subject areas and to evaluate its effectiveness. 


\section{References}

Ahmad, I., Said, H., \& Jusoh, A. (2015). Empirical evidence on the relationship between democratic classroom and social skills development of students. Mediterranean Journal of Social Sciences, 6(2), 18-27. https://doi.org/10.5901/mjss.2015.v6n2s1p18

Altuntaş, A. (2013). Kur’an'da temel siyasî kavramlar. Gümüşhane: Gümüşhane Üniversitesi Yayınları. [Basic political concepts in the Qur'an, Gumushane University Press.]

Andrade, H., Huff, K., \& Brooke, G. (2012). Assessing learning: The students at the center series. Students at the Center, 1-32. https://studentsatthecenterhub.org/resource/assessing-learning-the-student-atthe-center-series/

Arseven, Z., Şahin, Ş., \& Kılıç, A. (2016). Teachers' adaptation level of student-centered education approach. Journal of Education and Practice, 7(29), 133-144. https://www.researchgate.net/publication/322466177_Teachers'_Adaptation_Level_of_Student_Ce ntered_Education_Approach

Bayram-Jacobs, D., \& Hayırsever, F. (2016). Student-centred learning: How does it work in practice? British Journal of Education, Society \& Behavioural Science, 18(3), 1-15. https://doi.org/10.9734/BJESBS/2016/28810

Benesch, S. (1993). Critical thinking: A learning process for democracy. TESOL Quarterly, 27(3), 545-548. https://doi.org/10.2307/3587485

Blair, H. (2003). Jump-starting democracy: Adult civic education and democratic participation in three countries. Democratization, 1O(1), 53-76. https://doi.org/10.1080/714000108

Bostan, L. (2007). The opinions of high school biology teachers about student centered teaching and practical studies (Unpublished master's thesis). Marmara University Institue of Educational Science, İstanbul.

Botha, A., Joubert, I., \& Hugo, A. (2016). Children's perceptions of democratic values: Implications for democratic citizen education. South African Journal of Childhood Education 6(1), 1-8. https://doi.org/10.4102/sajce.v6i1.343

Brackenbury, T. (2012). A qualitative examination of connections between learner centered teaching and past significant learning experiences. Journal of the Scholarship of Teaching and Learning, 12(4), 12-28.

Carpenter, J. P., \& Pease, J. S. (2013). Preparing students to take responsibility for learning: The role of noncurricular learning strategies. Journal of Curriculum and Instruction, 7(2), 38-55. https://doi.org/10.3776/joci.2013

Çelik, N. (2018). Changing perception of state: From socialization to individuality. Istanbul Gelisim University Journal of Social Sciences (IGUJSS), 5(1), 60-78.

Claassen, C. (2019). In the mood for democracy? Democratic support as thermostatic opinion. American Political Science Review, 114(1), 36-53. https://doi.org/10.1017/Soo03055419000558

Collins, W. J. (2013). Education, democracy, and social discourse: A contemporary response to George S. Counts and Boyd H. Bode Schools: Studies in Education, 1O(2), 298-303.

Cook, S., \& Westheimer, J. (2006). Introduction: Democracy and education. Canadian Journal of Education, 29(2), 347-358. https://journals.sfu.ca/cje/index.php/cje-rce/article/view/2901

Davis, O. L. (2003). Editorial: Does democracy in education still live? Journal of Curriculum and Supervision, 19(1), 1-4. 
Demir, S. \& Özden, S. (2013). Primary school teachers' opinions of instructional strategies, methods and techniques: A descriptive study for scince of life class. Pamukkale University Journal of Social Sciences Institute, 14, 59-75. https://dergipark.org.tr/tr/pub/pausbed/issue/34728/383955

Dewey, J. (2001). Democracy and education. The Pennsylvania State University.

Diaz-Lefebvre, R. (2004). Multiple intelligences, learning for understanding, and creative assessment: Some pieces to the puzzle of learning. Teachers College Record, 106(1), 49-57. https://doi.org/10.1111/j.1467-9620.2004.00317.x

Duru, S. (2015). A metaphor analysis of elementary student teachers' conceptions of teachers in student- and teacher-centered contexts. Eurasian Journal of Educational Research, 6o, 281-300. https://doi.org/ 10.14689/ejer.2015.60.16

Edelstein, W. (2011). Education for democracy: Reasons and strategies. European Journal of Education, 46(1), 127-137. https://doi.org/10.1111/j.1465-3435.2010.01463.x

El-Gindi, K. M. (2008). The shura and human rights in Islamic law relevance of democracy (Translate: A. Kılınç). Journal of Islamic Law Studies, 12, 201-206.

Frambach, J. M., Driessen, E. W., Beh, P., \& Vleutenan, C. P. M. (2014). Quiet or questioning? Students' discussion behaviors in student-centered education across cultures. Studies in Higher Education, 39(6), 1001-1021. https://doi.org/10.1080/03075079.2012.754865

Frydenberg, M. (2012). Flipping Excel 2012 proceedings of the information systems. Proceedings of the Information Systems Educators Conference, New Orleans Louisiana, USA.

Garcia, S. (2018). Improving classroom preparedness using guided practice. SIGCSE '18: Proceedings of the 49th ACM Technical Symposium on Computer Science Education, pp. 326-331. https://doi.org/10.1145/3159450.3159571

Gollob, R., Krapf, P., Weidinger, W., \& O'lafsdottir, Ơ. (2010). Educating for democracy: Background materials on democratic citizenship and human rights education for teachers. Council of Europe Publishing.

Gömleksiz, M. N., \& Kan, A. Ü. (2008). Eğitim fakültesi ve tezsiz yüksek lisans programlarına kayıtlı öğretmen adaylarının demokratik tutumlarının değerlendirilmesi (Fırat Üniversitesi örneği). Milli Ĕgitim Dergisi, 37(178), 44-64.

Güleç, İ., Çelik, S., \& Demirhan, B. (2012). What is lifelong learning? An evaluation on definition and scope. Sakarya University Journal of Education, 2(3), 34-48.

Harber, C. (2002). Education, democracy and poverty reduction in Africa. Comparative Education, 38(3), 267-276. https://doi.org/10.1080/0305006022000014133

Heinö, A. J. (2009). Democracy between collectivism and individualism. De-nationalisation and individualisation in Swedish national identity. International Review of Sociology, 19(2), 297-314. https://doi.org/10.1080/03906700902833619

Herold, M. J., Lynch, T. D., Ramnath, R., \& Ramanathan, J. (2012). Student and instructor experiences in the inverted classroom. 42nd ASEE/IEEE Frontiers in Education Conference (FIE), pp. 1331-1336.

Hotaman, D. (2010). Democratic education: A curriculum of democratic education. Journal of Theoretical Educational Science, 3(1), 29-42.

Hurst, B., Wallace, R., \& Nixon, S. B. (2013). The impact of social interaction on student learning. Reading Horizons: A Journal of Literacy and Language Arts, 52(4), 375-398.

https://scholarworks.wmich.edu/reading_horizons/vol52/iss4/5 
Jacobs, G., \& Power, M. A. (2016). Student centered learning-An approach to fostering democracy in schools. Beyond Words, 4(2), 79-87.

Kılıç, A., Aydın, M., Ökmen, B., \& Şahin, Ş. (2019). Kuramdan uygulamaya ihtiyaç belirleme. Pegem Yayıncllk. https://doi.org/10.14527/9786052417133

Kovacs, P. (2009). Education for democracy: It is not an issue of dare; it is an issue of can. Teacher Education Quarterly, 36(1), 9-23. https://www.jstor.org/stable/23479198

Levin, B. (1994, February 24). Democracy and education, students and schools. Presented at the Conference “Under Scrutiny Again: What Kind of Secondary Schools Do We Need?”Vancouver, Canada.

Lind, G. (2018). Education for democracy fostering moral competence in the school and beyond. Annual Conference of the Association for Moral Education, Barcelona.

Maden, S., Durukan, E., \& Akbaş, E. (2011). İlköğretim öğretmenlerinin öğrenci merkezli öğretime yönelik algıları. Mustafa Kemal Üniversitesi Sosyal Bilimler Enstitüsü Dergisi, 8(16), 255-269.

Nagda, B. A., Gurin, P., \& Lopez, G. E. (2003). Transformative pedagogy for democracy and social justice. Race Ethnicity and Education, 6(2), 165-191. https://doi.org/10.1080/13613320308199

Okumuş, O., \& Güven, A. (2018). Some activities used for democracy education in history courses. The Journal of International Social Research, 11(56), 604-628. http://dx,doi.org/10.17719/jisr.20185639034

Okutan, M. (2010). Democracy education in Turkish education system. Journal of Human Sciences, 7(1), 938-946.

Ökmen, B. (2020). Developing the instructional process in layered flipped learning model (Unpublished PhD thesis). Duzce University Institue of Social Sciences.

Özpolat, A. (2010). Bir toplumsal değişme paradigması olarak demokrasinin eğitime yansımaları: Demokratik eğitim. [The reflections of democracy on education as a social change paradigm: Democratic education.] Milli Eğitim Dergisi, 4O(185), 365-381.

Patrick, J. J. (1986). Critical thinking in the social studies. ERIC Digest 3O. ED272432.

Petrova-Gjorgjeva, E. (2009). Democratic society and moral education. Procedia-Social and Behavioral Sciences, 2, 5635-5640. https://doi.org/10.1016/j.sbspro.2010.03.919

Platt, C. A., Raile, A. N. W., \& Yu, N. (2014). Virtually the same?: Student perceptions of the equivalence of online classes to face-to-face classes. MERLOT Journal of Online Learning and Teaching, 1O(3), 489-503.

Rainer, J., \& Guyton, E. (1999). Democratic practices in teacher education and the elementary classroom. Teaching and Teacher Education, 15, 121-132. https://doi.org/10.1016/So742-051X(98)ooo39-o

Ronkainen, N. J. (2014). Course preparation assignments: A tool to enhance independent learning, increase student participation, and performance in chemistry courses. Presented at the European Conference on Research in Chemistry Education 2014.

Saracaloğlu, A. S., \& Karasakaloğlu, N. (2011). The opinions of Turkish teachers on teaching methods and techniques. Elementary Education Online, 10(3), 951-960.

Saulnier, B. M., Landry, J. P., Longenecker, H. E., Jr., \& Wagner, T. A. (2008). From teaching to learning: Learner-centered teaching and assessment in information systems education. Journal of Information Systems Education, 19(2), 169-173. 
Schweisfurth, M. (2014). Learner-centred pedagogy: Towards a post-2015 agenda for teaching and learning. International Journal of Educational Development, 40, 259-266.

https://doi.org/10.1016/j.ijedudev.2014.10.011

Scott, J., Buchanan, J., \& Haigh, N.(1997). Reflections on student-centred learning in a large class setting. British Journal of Educational Technology, 28(1), 19-30. https://doi.org/10.1111/1467-8535.00003

Simó, N., Parareda, A., \& Domingo, L. (2016). Towards a democratic school: The experience of secondary school pupils. Improving Schools, 19(3) 181-196. https://doi.org/10.1177/1365480216631080

Starkey, H. (2005). Democratic education and learning. British Journal of Sociology of Education, 26(2), 299-308. https://doi.org/10.1080/0142569052000329200

Stone, B. B. (2012). Flip your classroom to increase active learning and student engagement. Paper presented at the 28th Annual Conference on Distance Teaching \& Learning, The Board of Regents of the University of Wisconsin System.

Subba, D. (2014). Democratic values and democratic approach in teaching: A perspective. American Journal of Educational Research, 2(12), 37-40. https://doi.org/10.12691/education-2-12A-6

Şahin, Ş. (2015). Improvement of instructional practices of Religious Culture and Moral Knowledge Course according to student-centered approach [Unpublished master's thesis], Duzce University Institue of Social Sciences.

Şahin, Ș. (2020). Compassionate love, democracy and student centered education perceptions of students, teachers and school principals [Unpublished PhD thesis]. Duzce University Institue of Social Sciences.

Şahinalp, H. (2017). From consultation to solidarity: Shura as an activation code of individual and social potentials. Journal of the Faculty of Divinity of Ankara University, 58(1), 109-146.

Şanl, Ö., \& Altun, M. (2015). The significance of establishing democratic education environment at schools. Journal of Educational and Instructional Studies in the World, 5(2), 1-8.

Tahiroğlu, M., \& Aktepe, V. (2015). The effect of activities developed appropriately to the values education methods upon democratic perception and behaviors. Journal of Values Education, 12(30), 309-345.

Talbert, R. (2012). Inverted classroom. Colleagues, 9(1), 1-3. https://scholarworks.gvsu.edu/colleagues/vol9/iss1/7

Varnham, S., Evers, M., Booth, T., \& Avgoustinos, C. (2014). Democracy in schools: Encouraging responsibility and citizenship through student participation in school decision making. International Journal of Law \& Education, 19(1), 73-91.

Vinterek, M. (2010). How to live democracy in the classroom. Education Inquiry, 1(4), 367-380. https://doi.org/10.3402/edui.v1i4.21951

Winton, S. (2008). Character education: Implications for critical democracy. International Critical Childhood Policy Studies, 1(1), 42-63.

Wolfe, A. B. (1923). Individualism and democracy. International Journal of Ethics, 33(4), 398-415. https://doi.org/ 10.1086/207409

Yadin, A., \& Or-Bach, R. (2010). The importance of emphasizing individual learning in the "collaborative learning era." Journal of Information Systems Education, 21(2), 185-194. https://aisel.aisnet.org/jise/vol21/iss2/5

Yamane, D. (2006). Course preparation assignments: A strategy for creating discussion-based courses. Teaching Sociology, 34(3), 236-248. https://doi.org/10.1177/0092055X0603400303 
Yargıcl, A. (2008). The shura according to some tafasir and its comparasion with democracy. Köprü, 103.

Yeşil, R. (2004). The method for human rights and democracy education. Journal of Kirşehir Faculty of Education, 5(1), 35-41.

Yeşilyurt, E. (2019). Investigation of teaching approaches, methods and techniques with regards to the suitability of values education: A review study. EKEV, 23(77), 121-146.

Ylldırım, C. (2018). The examination of the secondary education students' democratic citizenship attitudes towards the formal and hidden curriculum (Unpublished PhD thesis). Adnan Menderes University Institue of Social Sciences.

Zabeli, N., Anderson, J., \& Saqipi, B. (2018). Towards the development and implementation of learnercentered education in Kosovo. Journal of Social Studies Education Research, 9(4), 49-64. reviewed journal that provides a forum for studies and dialogue about developments and change in the field of education and learning. The journal includes research and related content that examine current relevant educational issues and processes. The aim is to provide readers with knowledge and with strategies to use that knowledge in educational or learning environments. JERAP focuses on education at all levels and in any setting, and includes peer-reviewed research reports, commentaries, book reviews, interviews of prominent individuals, and reports about educational practice. The journal is sponsored by The Richard W. Riley College of Education and Leadership at Walden University, and publication in JERAP is always free to authors and readers. 